\title{
Obituary John A Harvey
}

Neuropsychopharmacology (201 I) 36, 2786-2787; doi: |0.1038/npp.201 I.17|

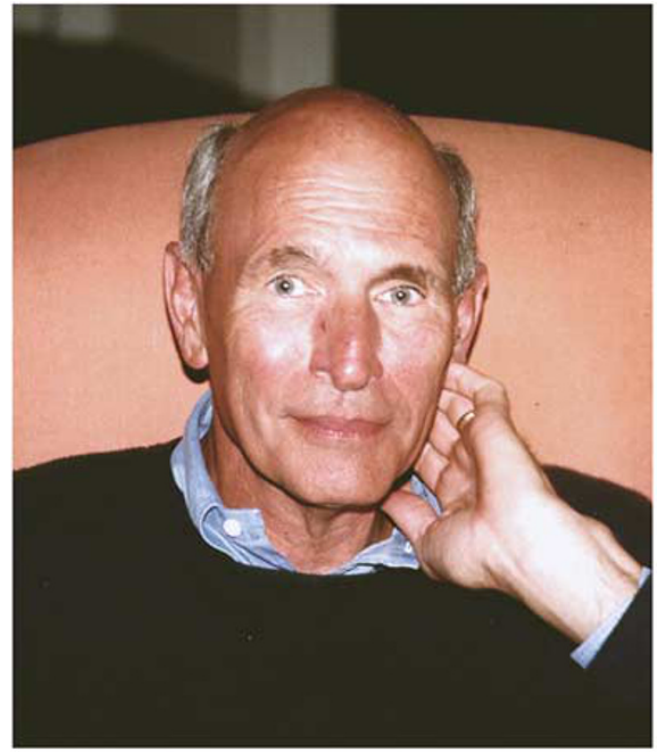

John A Harvey died on 25 June 2011, at the age of 80 . He was born in New York City, but was raised in Siberia by his grandparents during the first decade of his life. John completed his BA degree in 1955, received his $\mathrm{PhD}$ degree from the prestigious doctoral program in Biopsychology in 1959, and began his long and celebrated career as a faculty member, all at the University of Chicago. He moved to the University of Iowa in 1968, and then to Drexel University College of Medicine in the Department of Pharmacology and Physiology in 1988, where he served as Chair from 2006-2008.

John's research career is highlighted by many seminal scientific contributions related to the biochemistry of the brain and the development of behavioral pharmacology. While at Chicago, he laid the foundation for decades of investigations in neuropharmacology by seeking to explain how neurotransmitters within the central nervous system governed behavior and behavioral responses to drugs. He launched his career by establishing that monoamine neurotransmitters were organized into fiber tracts that could be identified and selectively destroyed to determine their behavioral functions. Once the brain was damaged, he showed that impaired behavioral functions could be recovered by restoring depleted neurotransmitters or stimulating denervated receptors. Using a model of increased pain sensitivity associated with serotonin depletion, he showed that the precursor 5-HTP could replenish 5-HT to

reverse that behavioral deficit. This remained a model for the treatment of neurological damage for years. He championed the transformative idea that medications used to treat psychiatric disorders produced their effects by modifying behavioral functions attributed to monoaminergic pathways. Subsequently, he established that the fenfluramine and amphetamines depleted brain 5-HT to produce neurotoxic effects, initiating investigations that continue in the substance-abuse field. He was among the first to recognize a relationship between brain lesions that destroyed dopaminergic fibers and deficits in feeding and other motivated behaviors.

As a lifelong student of the Russian physiologist Ivan Pavlov, John used Pavlovian conditioning of the rabbit nictitating membrane response for the past 25 years to understand how drugs influence learning. John identified the underlying neural circuitry in the rabbit brainstem required for associative learning and then established how drugs specifically altered different components of Pavlovian conditioning. His research established unequivocally that hallucinogenic drugs enhanced learning by activating $5-\mathrm{HT}_{2}$ receptors, and established key roles for these receptors in learning and cognition. At Drexel University, he established a NIDA program project that used Pavlovian conditioning to study the detrimental influence of prenatal exposure to cocaine on development. He also used Pavlovian conditioning to examine the effects of brain dysfunction related to autism, applying these techniques to a quest for translational biomarkers for this neurodevelopmental disorder.

John published over 150 peer-reviewed articles, reviews and book chapters, and his research contributions were recognized by numerous awards. His career achievements in serotonin research were honored by the Irvine $\mathrm{H}$ Page Award at the 2006 international meeting of the Serotonin Club. As a member of many professional societies in pharmacology and neuroscience, he contributed a lifetime of active service to the scientific community. Elected a member of the ACNP in 1979 and a Fellow in 1991, he served actively on the Committee on the Use of Animals. He was especially proud of serving the Journal of Pharmacology and Experimental Therapeutics as specific field editor and then editor-in-chief. He was a member of the editorial boards for more than 10 journals.

John was widely known and respected for his humor, collegiality and for his intelligence, and was considered by many to be the paramount gentleman. He trained many graduate students and postdoctoral fellows, many of whom developed their own productive and influential careers in biomedical research. John was the beloved husband to 
Dr Rhoda Harvey, and father to sons Michael (wife Pilar), Andrew (wife Sonya), and his eldest son, David, who predeceased him. He was also a loving grandfather to Oliver and Davia who brought him the greatest joy and pride. With his passing, many who are reading this commentary on John's life and contributions lost a cherished friend and dear colleague.
Irwin Lucki', James E Barrett ${ }^{2}$ and

$$
\text { Kenny J Simansky }{ }^{2}
$$

'Departments of Psychiatry and Pharmacology, University of Pennsylvania, Philadelphia, PA, USA;

${ }^{2}$ Department of Pharmacology and Physiology, Drexel University College of Medicine, Philadelphia, PA, USA E-mail: lucki@mail.med.upenn.edu 